\title{
Chemical contamination of water in irrigated rice on Paraná State, Brazil
}

\section{Contaminação química de água em arroz irrigado no estado do Paraná, Brasil}

\author{
Marcelo Luiz Chicati ${ }^{1 *}$; Marcos Rafael Nanni²; Everson Cézar ${ }^{3}$
}

\begin{abstract}
The objective of this study was to evaluate water contamination caused by chemicals used in rice irrigated cultivation of a small part of the Environmental Protection Area of the Islands and Floodplains of the Paraná River, specifically the portion covered by municipality Querência do Norte. This region is characterized by great natural wealth, as well the need for agricultural production. Four sections were made of water samples, two in summer and two in winter. These samples were at pre-established in rivers and drainage ducts that surround the area under cultivation, and the Ivaí River receiving water from these locations, using containers of $5 \mathrm{~L}$. To determine the concentration of herbicides, was used an aliquot of $250 \mathrm{~mL}$ of each sample, with a solution of hexane/dichloromethane, concentration of the extract and measure the volume of acetonitrile. The measurement was performed by high performance liquid chromatography with mass spectrometry sequence. The interpretation of obtained results demonstrated which presence of organophosphorus, methylcarbamates, chloroacetamides, triazoles, pyrethroids, triazines, pyrazoles and acetamides. The compound carbofuran is more abundant in the study area whereas the Atrazine and other compounds are not recommended for irrigated rice was founded in close regions to this area.
\end{abstract}

Key words: Oriza sativa, wetlands, pesticides, Ivaí river

\section{Resumo}

O objetivo deste trabalho foi avaliar a contaminação da água provocada pelo uso de agroquímicos na cultura de arroz irrigado em parte da Área de Proteção Ambiental das Ilhas e Várzeas do Rio Paraná, no município de Querência do Norte. Esta região é caracterizada por uma grande riqueza natural, bem como pela necessidade de produção agrícola. Foram realizadas quatro seções de coletas de água, sendo duas no verão e duas no inverno, que ocorreram em pontos pré-estabelecidos, nos rios e canais de drenagem em torno das áreas de cultivo de arroz, inclusive no rio Ivaí que é receptor de águas destes locais, utilizando-se galões de 5 litros. Para determinação da concentração dos herbicidas, foi utilizada alíquota de $250 \mathrm{~mL}$ de cada amostra, com solução hexano/diclorometano, concentração do extrato e aferição do volume em acetonitrila. A medição foi realizada por cromatografia líquida de alta eficiência com espectrometria de massa sequencial. Os resultados demonstraram presença de Organofosforados, Metilcarbamatos, Cloroacetamidas, Triazóis, Piretróides, Triazinas, Acetamidas e Pirazóis. O composto Carbofurano é o mais abundante na área de estudos. A Atrazina é encontrada e determinada como originária de regiões próximas à área de estudo. Além da Atrazina, outros compostos não recomendados para arroz irrigado são usados nesta região, sendo passíveis de ações legais para punição.

Palavras-chave: Oriza sativa, várzeas, pesticidas, rio Ivaí

\footnotetext{
${ }^{1}$ Prof. Dr. do Dept ${ }^{\circ}$ de Engenharia Civil, Centro de Tecnologia, Universidade Estadual de Maringá, UEM, Maringá, PR. E-mail: mlchicati@hotmail.com

${ }^{2}$ Prof. Dr. do Dept ${ }^{\circ}$ de Agronomia, Centro de Ciências Agrárias, UEM, Maringá, PR. E-mail: mrnanni@uem.br

${ }^{3}$ Doutorando do Dept ${ }^{\circ}$ de Agronomia, Centro de Ciências Agrárias, UEM, Maringá, PR. E-mail: eversoncezar@yahoo.com.br

* Autor para correspondência
} 
The impact of human activity on an area can be easily measured by the quality of surface water diagnosis (BORTOLUZZI et al., 2006). The Brazil, since the 70's, stands out as one of the world's largest consumers of pesticides. However, as it provides the only indication of the pesticides application scale are the online marketing values, from which there is a great use of herbicides (PRIMEL et al., 2005). Crops responsible for this high consumption are mainly soybean, sugar cane, corn and rice.

With emphasis on the international stage, the Brazil is today the largest rice producer outside the Asian continent. In Paraná State, according to CONAB (Companhia Nacional de Abastecimento), the cultivation area is 2.553 hectares, producing about $11.462,1$ tons with a yield of $4.490 \mathrm{~kg} \mathrm{ha}^{-1}$ (CONAB, 2012).

The main producing region of Paraná State is among the municipalities of Querência do Norte and Santa Cruz do Monte Castelo, which is responsible for approximately $95 \%$ of state production. This region is located in the Environmental Protection Area of the Islands and Floodplains of the Paraná River, comprising mainly wetlands, flood plains and other special sites located on the right bank of the Ivaí River.

These regions are known to undergo massive influence of the floods which affect the productivity of local crops (CHICATI et al., 2009). Within the legal aspect, are difficult areas for action or implementation of measures to protect or maximize the production of local crops, since the seasonal influence of the floods with Paraná and Ivaí rivers cannot be determined in specific time periods.

In irrigated rice system is the release of water to the ducts and rivers that need to be monitored due to the effects of pesticides concentrations (CREPEAU; KUIVILA, 2000). Depending on the water management used by producers and conditions of rainfall after the applications, there is a risk of chemical residues from the production process of agricultural crops affect aquatic organisms in waters downstream (RESGALLA JÚNIOR et al., 2002). It is worth emphasizing the importance of considering the contamination of other ecosystem components such as air, soil, sediment and plant when required.

The main contaminants of agricultural origin are the residues of fertilizers and pesticides. These products, when applied on the culture fields, may reach water bodies directly, through the rain water and irrigation, or indirectly through percolation into the soil, reaching groundwater (ARIAS et al., 2007). The monitoring of water quality parameters is itself basic tool to assess environmental changes caused by action of man (MOLOZZI; PINHEIRO; SILVA, 2006).

A CONAMA Resolution 357/05 establishes quality standards for surface water providing the maximum allowable concentrations for each water body, depending on the predominant uses. Most studies assessing the impacts generated by production activities consider the variation in the concentration of pollutants (MASCARENHAS; BRABO; SILVA, 2004; CUNHA; CUNHA; BRASIL JUNIOR, 2005).

Thus, this study was conducted to evaluate the contamination levels caused by some chemicals used in rice cultivation on the waters of Environmental Protection Area of the Islands and Floodplains of the Paraná River small part, specifically the portion covered by the municipality Querência do Norte. This region is characterized by great natural wealth, as well a great need for agricultural production.

The study area is located in the northwestern region of Paraná State and is included in the Federal Environmental Protection Area of Islands and Floodplains from Paraná River. This APA was bounded a pilot area for the studies, which is located by UTM coordinates, in the $51^{\circ}$ meridian W.G., 238 - $252 \mathrm{~km}$ and $7428-7438 \mathrm{~km}$ from Ecuador and geographic coordinates $22^{\circ} 30^{\prime}$ to $23^{\circ} 25^{\prime}$ south and $52^{\circ} 45^{\prime}$ to $53^{\circ} 45^{\prime}$ west, with total area of $59.5 \mathrm{~km}^{2}$.

The study area is mainly drained by the Ivaí River, one of the most important of the state and also 
the longest, with $685 \mathrm{~km}$ long. Its main tributaries in the main bed are Corumbataí and Mourão Rivers (on left) and Alonzo River (on right), but in the principal region there are the Prata and Caveira Rivers.

Water samples for analysis of organic and inorganic contamination were taken from the existing drainage ducts between the Prata and Caveira Rivers, surrounding areas of rice plantation and the Ivaí River, which receives the surplus not used in process at the time of flood or drainage to soil preparation or harvest. For this collection, plastic containers with 5 liters capacity were used at previously established standards for collection. The process of samples collection followed the standards set by the NBR 9898 (1987).

Were made four sections of collections, two during the winter (dry), where the water table had lowered themselves to soil preparation and planting activities and two others during the summer, in the period of flooding, to evaluate the presence of used products in farming. The collections were performed in June 2006, March 2007, August 2007 and November 2007.

To determine the herbicides concentration, was used an aliquot of $250 \mathrm{~mL}$ each sample, partition liquid-liquid solution with hexane/dichloromethane, extract concentration and volume measure in acetonitrile. The measurement was performed by high performance liquid chromatography with sequential mass spectrometry (LC-MS/MS) according to Ardrey e Ardrey (2003).

All samples were sent to the Office Technology of the Paraná State (TECPAR) to assess the organic and inorganic levels of contaminants most commonly used in Paraná State in the rice cultivation, such compounds listed or not for such cultivation.

Among the compounds and products determined by liquid chromatography and mass spectrometry sequencing include: Benzimidazole: carbendazin, thiabendazole and methyl thiophanate; Carbamates: aldicarb, aldicarb sulfone, carbaryl, carbofuran, hydroxy-carbofuran, methiocarb, methomyl, and propoxur promecarbe; Compounds containing sulfur and/or nitrogen: azoxystrobin, fipronil, pendimethalin, trifluralin and propargite; Organochlorines: alachlor, folpet, metolachlor, propiconazole and tebuconazole; Organophosphorus: acephate, azinphos methyl, chlorpyrifos, diazinon, dichlorvos, dimethoate, etiona, fenitrothion, fenthion, phorate, phosmet, malathion, methidathion, parathion, methyl pirimiphos and terbufos; Pyrethroids: bifenthrin, cypermethrin, deltamethrin, fenvalerate and permethrin; Triazines: atrazine and simazine. For each sampled point was realized a battery of tests to detect the compound.

The tests battery determined compounds varied in different seasons, using the criterion for removal the agrochemicals consumption in the region. The laboratory results obtained are presented divided in Tables 1 and 2. Next, were analyzed the compounds in Table 1.

The first group shown in Table 1 is organophosphorus products and is reviewed here as chlorpyrifos and fenthion. The insecticide chlorpyrifos has a broad action spectrum and high risk to health. Subject of discussion in the courts, the use of this product was banned by the National Sanitary Surveillance Agency (ANVISA) through RDC Resolution No 226 of 28 September 2004 and restored its effects by STF on 11 July 2005. According to its specifications, it is not recommended for growing rice. Its half life varies from 60 to 120 days, but can get to a year depending on soil conditions, weather etc.

According to EPA (2002), chlorpyrifos is moderately toxic to humans may affect the central nervous systems, cardiovascular and respiratory, and can irritate the skin and eyes. With broad spectrum and low cost ends up being used indiscriminately, causing huge losses to the environment. 


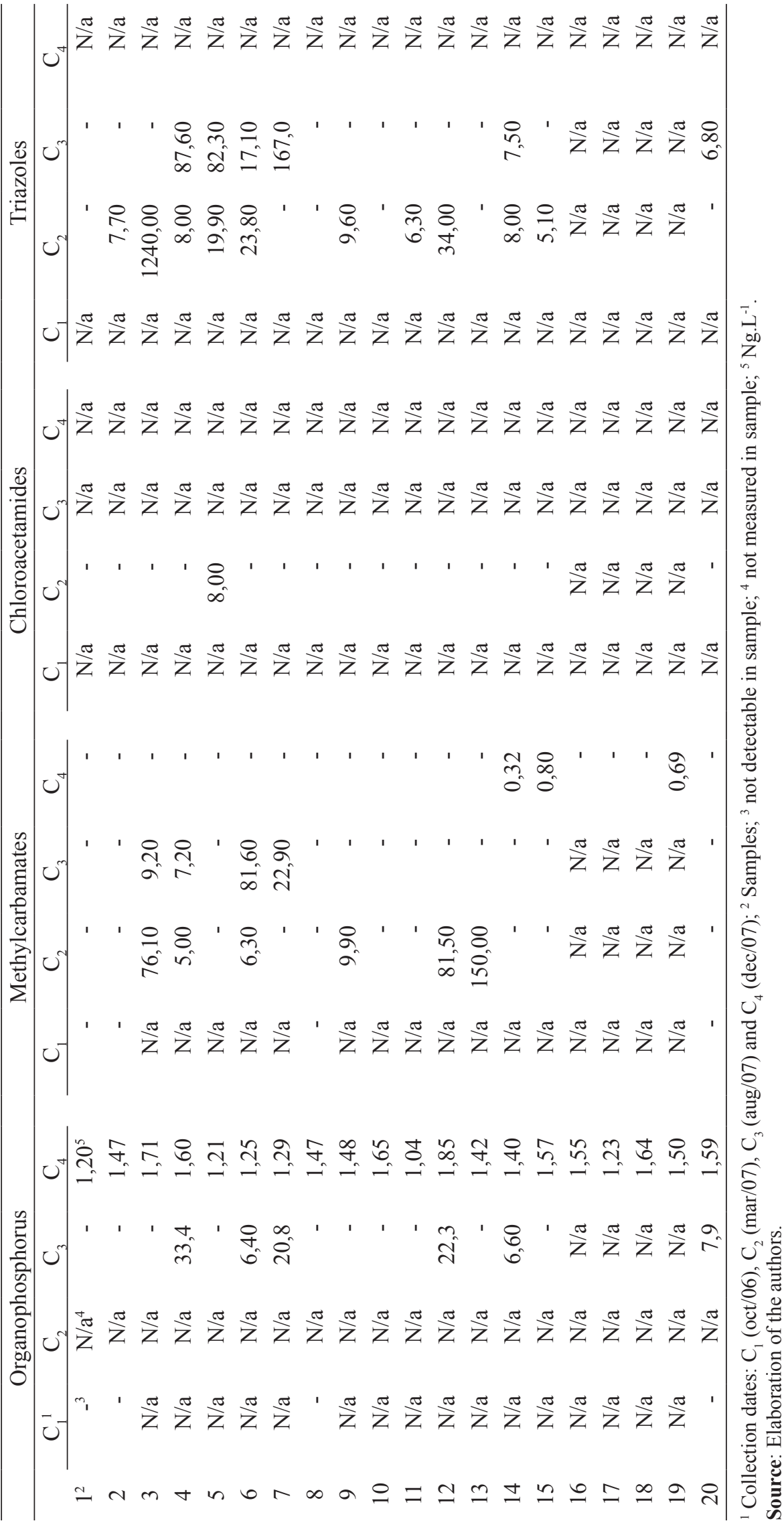


The chemical compound fenthion is used as an insecticide/acaricide in many commercial crops. Its use in rice is not known. However, for Paraná State there's no restriction on their use, but it is not registered for that crop. The fenthion is considered highly toxic (class II) by oral route and moderately toxic if in contact with the human skin.

The chemical group of methylcarbamates was also found in various parts of the study area, in the forms of Carbofuran and Carbaryl. The Carbofuran has a broad spectrum with an insecticide/nematicide that kills by contact or ingestion, considered highly toxic by inhalation and ingestion. It is soluble in water and moderately persistent in soil, with half life of 30 to 120 days, and therefore has great potential for contamination of water bodies, especially in sandy soils such as the study area.

The insecticide Carbaryl is considered a highly toxic and not recommended for growing rice. Displays small spectrum, specific to some 100 species of insects. It can also be used to control nematodes and mollusks. Can produce variety of adverse effects in the human body and other organisms either by contact, inhalation or ingestion.

The Carbaryl shows little persistence in the soil, because their degradation is rapid in action of the sun and decomposition by bacteria (EPA, 2002). Shows half life of 7 to 14 days in sandy soils and 14 to 28 days in clay soils. In the water surface the same author stated that their presence is small, since the product is decomposed by soil bacteria having half life below 10 days in conditions of neutral $\mathrm{pH}$, such as rice when it provides a water layer.

By observing Table 1 it can be noted that Chloroacetamide (Metolachlor), comes in only one point of collection (5). Thus, was observed in the study area which there is no frequent use of this product, it is mainly carried by the waters of Ivaí River. This condition is worrying, given that almost all chemical compounds are found present in the river water, which in his condition for the level lifting during the rainy season can cause flooding of the system as a whole, leading to its contamination, also detected by Resgalla Júnior et al. (2002). This product is not registered for irrigated rice in Paraná State. Its presence is not disturbing to humans and birds since it is not considered carcinogenic (EPA, 2002).

It was observed that among the items analyzed, in the point 5 was founded the most of pesticides. At this point, found herbicides and fungicides, probably used in large cultivated large areas differently in all regions of the northwest state. The products of the triazoles chemical group are classified according to EPA (2002) as carcinogenic in group C (with the possibility of carcinogenicity to humans). Commercial products such as Constant, Folicur and Elite, are released by the Paraná State agriculture secretary for treatment of fungal diseases (leaf and the bunch), except for blast (Pyricularia grisea (Cooke) Sacc). Therefore, these products found in the trash come from residual or harvest rice in direct contact with surface water, since this development stage it is under a water layer.

It is known today that this contaminant is persistent and relatively immobile in soil. This condition is exacerbated by the fact that the entire production system requires this component, which is the basic condition for the control of fungal diseases. So, this is a product that should be used with caution by producers, should be thought on safer alternatives for foliar diseases control in irrigated rice (resistant cultivars, appropriate planting seasons etc).

Below, in Table 2, are presented more four chemical groups examined in this study.

For Table 2 were find the presence of the Pyrethroids group only in one point of analysis, as Deltamethrin. However, this collection refers to a large dam, responsible for all water distribution in the flooded most dry seasons in addition to being used for recreation, feeding fish and human and animal consumption. His performance occurs by contact or ingestion. Its use is permitted in rice cultivation for Paraná State. It has a large control 
broad spectrum and is considered the most powerful of the synthetic market Pyrethroids.

As any insecticide, its use can eliminate bees and other human interest insects. The great advantage in use of this pesticide is its rapid soil degradation (about 2 weeks) and very complex with water colloids.

Table 2 is also observed the presence of triazines, mainly in Atrazine form. This herbicide is used for corn, sugar cane and sorghum and can be applied to immediately pre or post-emergency. This product is not registered for rice cultivation.

Maize crops were located near the point 2, showed drift occurrence to within the study area, characterizing external contamination.

Atrazine is designated as Class III or moderately toxic to both humans and other animals (EPA, 2002). It can be absorbed orally, through skin or inhalation. The found values are well above those allowed by EPA, being considered as highly contaminated system.

The Acetamide group is presented in Table 2, on carbendazin form. This is a systemic fungicide used to control diseases, especially of soybeans, beans, wheat and cotton. It is not recommended for irrigated rice.

The collection points where the product was found are in areas close to rice, but not necessarily in the culture field. This product is probably used in rice leaf diseases control or other crops (wheat). As its residual effect is very small, it's believed that invades the flooded area by its artificial drainage ducts. For to be slightly toxic (class III), this product does not present risks to human health are not considered carcinogenic or mutagenic.

Another chemical group showed in the Table 2 is the Pyrazols, in form of Fipronil. This compound is a broad spectrum insecticide that damages the insect central nervous system blocking the chloride ions passage through GABA receptors and channels in glutamate-chlorine (GluCl), components of the central nervous system.

About Fipronil degradation in aquatic environment, Connelly (2001) describes possible transformation in another product, also toxic for insects, called disulfenil photodegrades. With regard to possible impacts caused by Fipronil to human health Connelly (2001) conducted experiments with rats verified the occurrence of tumors in both sexes. There is, therefore, the possibility of the insecticide present high carcinogenic potential in humans, although framed by the EPA in Group C (possibly carcinogenic to humans). In agriculture this product is widely used to ant's control.

Except for the first sampling round, carbofuran is the composed of higher occurrence in study area, followed by Tebuconazole.

The Atrazine was founded in several samples, with different source, either by cultures external to the study area or water coming from the Ivaí River.

Chemicals not authorized by the Paraná State Secretary of Agriculture and Supply are used to control diseases and pests in irrigated rice, being liable to punishment. 


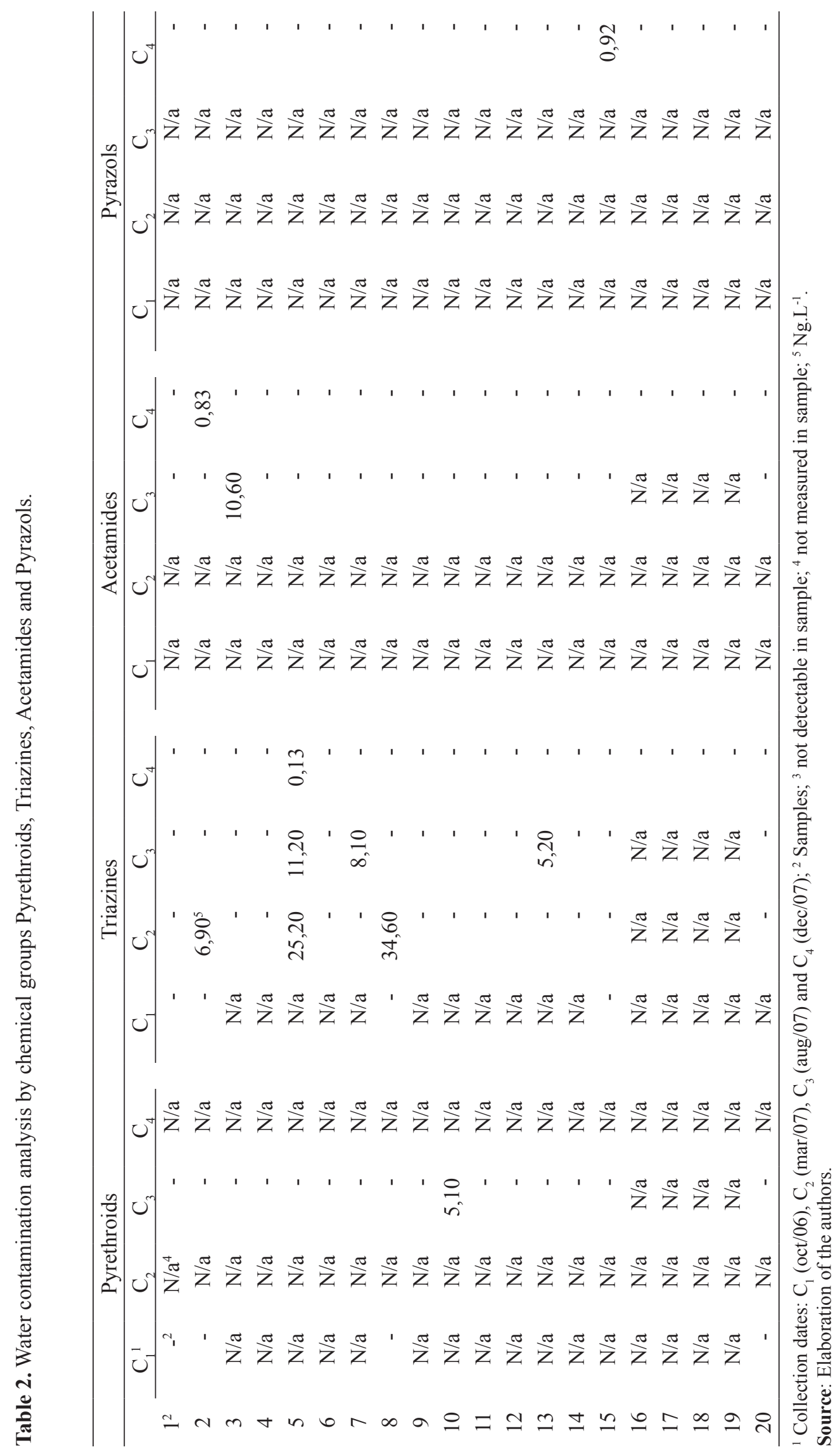




\section{References}

ASSOCIAÇÃO BRASILEIRA DE NORMAS TÉCNICAS. NBR 9898: preservação e técnicas de amostragem de afluente líquidos e corpos receptores procedimento. Rio de Janeiro, 1987.

ARDREY, R. E.; ARDREY, R. Liquid chromatographymass spectrometry: an introduction. London: J. Wiley, 2003.

ARIAS, A. R. L.; BUSS, D. F.; ALBURQUERQUE, C.; INÁCIO, A. F.; FREIRE, M. M.; EGLER, M.; MUGNAI, R.; BAPTISTA, D. F. Utilização de bioindicadores na avaliação de impacto e no monitoramento da contaminação de rios e córregos por agrotóxicos. Ciência \& Saúde Coletiva, Rio de Janeiro, v. 12, n. 1, p. 61-72, 2007.

BORTOLUZZI, E. C.; RHEINHEIMER, D. S.; GONÇALVES, C. S.; PELLEGRINI, J. B. R.; ZANELLA, R.; COPETTI, A. C. C. Contaminação de águas superficiais por agrotóxicos em função do uso do solo numa microbacia hidrográfica de Agudo, RS. Revista Brasileira de Engenharia Agrícola e Ambiental, Campina Grande, v. 10, n. 1, p. 881-887, 2006.

CHICATI, M. L.; NANNI, M. R.; OLIVEIRA, R. B.; CÉZAR, E. Levantamento e caracterização dos solos de uma região de várzeas da APA das Ilhas e Várzeas do Rio Paraná. Agropecuária Técnica, Areia, v. 30, n. 1, p. 10-15, 2009.

COMPANHIA NACIONAL DO ABASTECIMENTO CONAB. Acompanhamento da safra brasileira: grãos quarto levantamento, 2012. Brasília: CONAB, 2012.

CONNELLY, P. Environmental fate of fipronil. California Environmental Protection Agency: Department of Pesticide Regulation, 2001.
CREPEAU, K. L.; KUIVILA, K. M. Rice pesticide concentrations in the Colusa basin drain and the Sacramento River, California, 1990-1993. Journal of Environmental Quality, Madison, v. 29, n. 3, p. 926-935, 2000.

CUNHA, A. C.; CUNHA, H. F. A.; BRASIL JUNIOR, A. C. P. Microbiologic water quality in urban and Periurban Rivers on low Amazon River - study of case: Amapá State. Engenharia Sanitária Ambiental, Rio de Janeiro, v. 9, n. 1, p. 322-328, 2005.

ENVIRONMENTAL PROTECTION AGENCY - EPA. Health effects support document for manganese external review draft. Washington: U. S. EPA, 2002.

MASCARENHAS, A. F. S.; BRABO, E. S.; SILVA, A. P. Mercury concentration assessment in bottom sediments and suspended solids from Acre River, in the State of Acre, Brazil. Acta Amazonica, Manaus, v. 34, n. 1, p. 6168, 2004.

MOLOZZI, J.; PINHEIRO, A.; SILVA, M. R. Qualidade da água em diferentes estádios do desenvolvimento do arroz irrigado. Pesquisa Agropecuária Brasileira, Brasília, v. 41, n. 1, p. 1393-1398, 2006.

PRIMEL E, G.; ZANELLA, R.; KURZ, M. H. S.; GONÇALVES, F. F.; MACHADO, S. O.; MARCHEZAN, E. Poluição das águas por herbicidas utilizados no cultivo de arroz irrigado na região central do estado do Rio Grande do Sul, Brasil: Predição teórica e monitoramento. Química Nova, São Paulo, v. 28, n. 1, p. 605-609, 2005.

RESGALLA JUNIOR, C.; NOLDIN, J. A.; SANTOS, A. L.; SATO, G.; EBERHARDT, D. S. Toxicidade aguda de herbicidas e inseticida utilizados na cultura do arroz irrigado sobre juvenis de carpa (Cyprinus carpio). Revista Ecotoxicologia e Meio Ambiente, Curitiba, v. 12, n. 1, p. 59-68, 2002. 